\title{
Vehicle Thermal Microclimate Evaluation during Brazilian Summer Broiler Transport and the Occurrence of PSE (Pale, Soft, Exudative) Meat
}

\author{
Gislaine Silveira Simões ${ }^{1}$, Alexandre Oba ${ }^{2}$, Tiemi Matsuo ${ }^{3}$, Alessandro Rossa ${ }^{4}$, Massami \\ Shimokomaki ${ }^{1}$ and Elza Iouko Ida ${ }^{1 *}$ \\ ${ }^{1}$ Departamento de Ciência e Tecnologia de Alimentos; Universidade Estadual de Londrina; C. P.: 6001; 86051- \\ 970; Londrina - PR - Brasil. ${ }^{2}$ Departamento de Ciência Animal; Centro de Ciências Agrárias; Universidade \\ Estadual de Londrina; C. P.: 6001; 86051-970; Londrina - PR - Brasil. ${ }^{3}$ Departamento de Estatística; Londrina - \\ PR - Brasil. ${ }^{4}$ Rua Claudio Zatta, 35; Cafelândia - PR - Brasil
}

\begin{abstract}
The formation of a thermal microclimate within the vehicle during the transport of broilers from farm to slaughterhouse affects the birds' welfare and potentially promotes the development of PSE meat. Thus, the aim of this work was to evaluate the effects of routine commercial practices on the vehicle microclimate formed during transportation of broilers. Twenty-four hours postmortem Pectoralis major m. samples were classified as PSE meat by determining $\mathrm{pH}$ and color $\left(L^{*}, a^{*} e b^{*}\right)$. Results showed that broiler located at the rear of the truck and with longer journey presented higher amounts of PSE meat because birds were under harsh conditions of both temperature and relative humidity. The ventilation decreased gradually from the front to the rear of the truck, and the water bath at the farm was beneficial over a long distance by reducing the overall occurrence of PSE meat.
\end{abstract}

Key words: animal welfare, poultry meat quality, thermal stress, poultry breast meat, color abnormality

\section{INTRODUCTION}

Previous work described for the first time the effect of broiler management practices at the farm and during transportation from the farm to the slaughterhouse on the occurrence of PSE in breast fillet meat in the Brazilian winter (Langer et al., submitted). The present work reports further results obtained in an experiment carried out in the summer to evaluate the effect of routine commercial practices on the vehicle microclimate formed in transit and its influence on the formation of PSE meat. The variables monitored were time/distance, temperature, relative humidity, and ventilation by anemometers located at the front, middle and rear regions of the vehicle. While in transit, broilers are subject to various potential stressors in trucks, such as heat, acceleration, vibration, movement, impact, food and water deprivation, social disruption, and noise (Nicol and Scott, 1990, Mitchell and Kettlewell, 1998). Other conditions, such as the number of birds in the individual crate, heat and moisture production, and the internal vehicle ventilation, should also be

Author for correspondence: elida@uel.br 
considered. In order to maintain a refreshing climate for birds in transit, it is routine practice to submit them to a water bath for a few minutes just before beginning the journey. However, studies on the subject in Brazil have not related animal welfare and the subsequent meat quality. Finally, the holding period at the processing plant before slaughtering was also considered. Under Brazilian commercial practice, birds are normally kept in the shade upon arrival and submitted to water misting for up to 1 or $2 \mathrm{~h}$ in order to calm them down and thus help their bodies return to homeostasis (Guarnieri et al., 2004). Under these conditions of transport, broilers face thermal stress and therefore develop PSE meat (Olivo et al. 2001, Guarnieri et al., 2004, Soares et al., 2002). The objective of this work was to evaluate the influence of broiler transport conditions in the Brazilian summer season on the formation of PSE meat.

\section{MATERIALS AND METHODS}

\section{Animals}

The present experiment was carried out in southern Brazil in December 2008 in a commercial plant integrated with chicken broiler farms in a cooperative system. A number of 360 broilers from each of two farms located at $15 \mathrm{~km}$ and 55 $\mathrm{km}$ away from the processing plant, for a total of 720 birds. These birds were at 44 days of age, of mixed sex, and of commercial lineage.

\section{Microclimate measurement}

The measurement of temperature $(\mathrm{T})$, relative humidity (RH), and ventilation (VT) within the transport containers was undertaken using an thermoanemometers (Kestrel 4000) installed to record at $5 \mathrm{~min}$ intervals throughout the journey. $\mathrm{T}$, RH, and VT data were subsequently downloaded directly to a personal computer. The commercial broiler transport vehicle consisted of an open truck. Birds were loaded in crates containing 7 to 8 birds each and the capacity of each vehicle was approximately 3,000 birds. Two anemometers were installed in three locations at front, middle, and rear of the truck, and values of $\mathrm{T}, \mathrm{RH}$, and VT were thus representative of the heterogeneous distribution of the thermal microclimate within the loaded vehicle. Fig 1A shows the position of these anemometers at $1.5 \mathrm{~m}$, $4.5 \mathrm{~m}$, and $8.5 \mathrm{~m}$ from the front of the transport container, with one placed at a height of $0.84 \mathrm{~m}$ and the other at $2.25 \mathrm{~m}$. All anemometers were placed in the middle of the truck, as shown in Fig $1 \mathrm{~B}$.

In order to evaluate the effect of administering a water bath just before the journey, trucks were divided into those with birds submitted to a bath (LwiB) $(\mathrm{n}=360)$ and those with birds without a bath $(n=360)(L w o B)$ at the farm. Upon arrival at the processing plant, the trucks were driven to holding places where the birds were left at rest while they were submitted to a water mist and ventilation for $60 \mathrm{~min}$ before slaughtering.
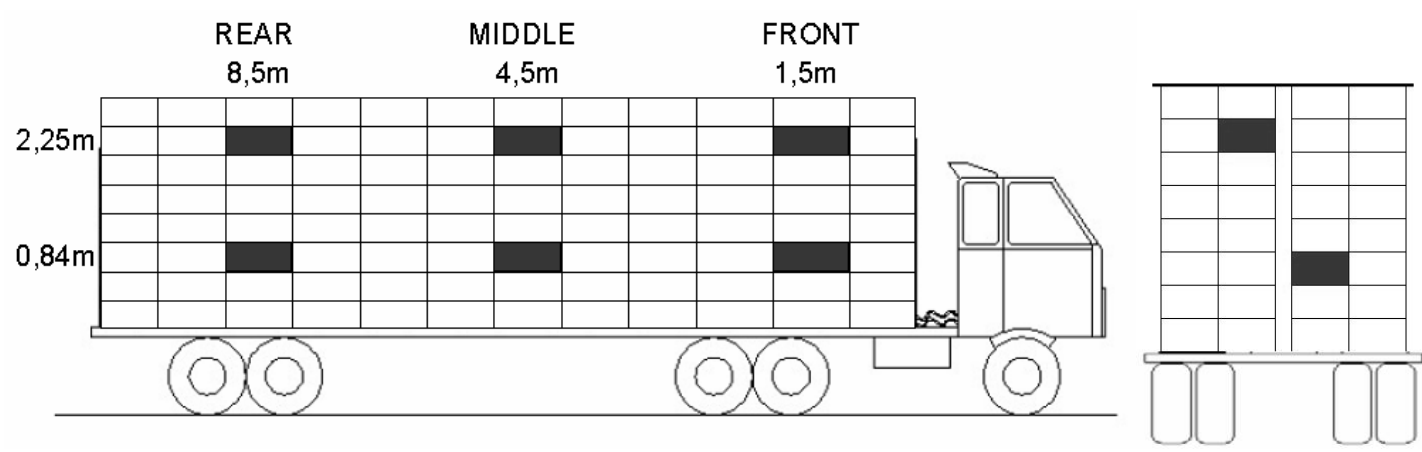

A

B

Figure 1 -A) Installation locations of six anemometers at the front, middle and rear of the truck. B) A view from the back of the thermoanemometers installation locations within the vehicle. (Adapted from Barbosa Filho, 2008). 


\section{Broiler slaughtering}

All birds were sacrificed following the routine procedures of a commercial plant, which followed a sequence of electrical stunning, bleeding, defeathering, evisceration, carcass water-cooling, deboning, and refrigeration.

\section{pH measurement}

The $\mathrm{pH}$ was measured by inserting electrodes into the breast muscle using a $\mathrm{pH}$ meter system (Mettler, model Toledo 345). Analyses were performed in triplicate at $24 \mathrm{~h}$ postmortem, following Olivo et al. (2001).

\section{Color measurement}

A Minolta CR10 colorimeter was used to evaluate the color, and a CIELAB system was used to evaluate the lightness $\left(\mathrm{L}^{*}\right)$ of the posterior surface of the intact skinless breast muscles at $24 \mathrm{~h}$ postmortem. The $\mathrm{L}^{*}$ values were measured at three different sites on the same sample. These sites were the proximal extremity of the muscle and the distal, and the medial side halfway between the proximal and distal extremities (Soares et al., 2002).

\section{Sample classification}

Meat samples were classified as PSE or normal based on previously established parameters associated with $\mathrm{pH}$ and $\mathrm{L}^{*}$. Values of $\mathrm{L}^{*} \geq 53.0$ were classified as PSE and $44.0<\mathrm{L}^{*}<53.0$ as normal (Soares et al., 2002).

\section{Broiler thermal comfort enthalpy index determination}

Microclimate thermal welfare was evaluated by an enthalpy calculation $(\mathrm{H})$ through the Comfort Enthalpy Index (CEI). The $\mathrm{H}$-value was measured for the three vehicle regions as follows:

$$
H=6.7+0.243 \times T d b+\left\{\begin{array}{l}
\frac{7.5 \times T d b}{237.3+T d b} \\
\frac{\mathrm{RH}}{100} \times 10^{20}
\end{array}\right\} \times 4.18
$$

$\mathrm{H}=$ Enthalpy $(\mathrm{kJ} / \mathrm{kg}$ dried air)

$\mathrm{Tdb}=$ temperature of dried bulb $\left({ }^{\circ} \mathrm{C}\right)$

$\mathrm{RH}=$ Relative humidity $(\%)$

The obtained results were analyzed using an enthalpy table according to Barbosa Filho et al. (2008).

\section{Statistical analysis}

The program Statistica 7.0 for Windows was used to apply the Tukey test (5\%) to detect differences for $\mathrm{pH}$ and color values determined for breast meat $\mathrm{pH}_{24}$ and the differences for $\mathrm{T}, \mathrm{RH}, \mathrm{VT}$ and $\mathrm{H}$ values for the three vehicle regions. The Pearson coefficient test with $1.0 \%$ probability was applied to measure the correlations between $\mathrm{pH}$ and $\mathrm{L}^{*}$, $\mathrm{pH}$ and $\mathrm{a}^{*}$, and $\mathrm{pH}$ and $\mathrm{b}^{*}$. Logistic regression analysis (Hosmer and Lemerhow, 1989; Terzin et al., 1997) was applied to verify the effect of transportation distance/time, location of the crate, and the application of the water bath at the farm on the occurrence of PSE meat.

\section{RESULTS AND DISCUSSION}

\section{Thermal truck microclimate characterization}

Table 1 presents the road types, times of transport, ventilation speeds, and holding times at the slaughterhouse for both lots of LwoB and LwiB transported distances, 15 and $55 \mathrm{~km}$. The transport times were 30 and $90 \mathrm{~min}$ for the two distances, respectively, the average speeds were 30 and 38 $\mathrm{km} / \mathrm{h}$, respectively, and the holding times were 60 and $50 \mathrm{~min}$, respectively. The use of a water bath before the journey is an important technique for aiding the birds in reaching body homoeostasis, as previously observed (Guarnieri et al., 2002).

Table 1 - Characteristics of broiler transportation from the farm to slaughterhouses at distances of 15 and $55 \mathrm{~km}$ and length of the holding period before slaughtering.

\begin{tabular}{ccccccc}
\hline \multirow{2}{*}{ Distance (km) } & \multicolumn{2}{c}{ Transportation time (min) } & \multicolumn{2}{c}{ Truck velocity (km/h) } & \multicolumn{2}{c}{ Holding period (min) } \\
\cline { 2 - 7 } & LwoB & LwiB & LwoB & LwiB & LwoB & LwiB \\
\hline 15 & 30 & 30 & 30 & 30 & 60 & 60 \\
55 & 90 & 90 & 38 & 38 & 50 & 50 \\
\hline
\end{tabular}

LwoB $=$ Broiler lot without bath. LwiB = Broiler lot with bath. 
Table 2 shows the ambient and microclimate temperatures and relative humidity values from three truck regions and also the ventilation air speed and enthalpy of LwoB and LwiB transported $15 \mathrm{~km}$. The monitored ambient temperatures were 29 and $31^{\circ} \mathrm{C}$ throughout the experiment for LwoB and LwiB, respectively, on the same day but at different loading times. The microclimate for LwoB presented temperatures that were higher than the ambient temperature by 1.6, 3.7, and $4.3^{\circ} \mathrm{C}$ in the front, middle, and rear regions, respectively (Table 2). These results illustrated a better distribution of truck ventilation from the vehicle front to rear.

Table 2 - Average values of temperature $\left({ }^{\circ} \mathrm{C}\right)$ and relative humidity $(\%)$ of ambient and at vehicle microclimate at the front, middle, and rear regions, Ventilation (VT) $(\mathrm{m} / \mathrm{s})$, and Enthalpy $(\mathrm{H})(\mathrm{kJ} / \mathrm{kg}$ dry air) of the broiler lot without bath (LwoB) and with bath at the farm (LwiB) for the $15 \mathrm{~km} / 30 \mathrm{~min}$ slaughter processing plant.

\begin{tabular}{|c|c|c|c|c|}
\hline Vehicle regions & $\mathbf{T}^{\circ} \mathbf{C}$ & RH\% & VT $\mathbf{m} / \mathbf{s}$ & H kJ/kg dry air \\
\hline \multicolumn{5}{|l|}{ LwoB } \\
\hline Front & $30.6^{\mathrm{c}}( \pm 0.4)$ & $56.6^{\mathrm{b}}( \pm 8.2)$ & $2.17^{\mathrm{a}}( \pm 2.2)$ & $76.1^{\mathrm{c}}( \pm 1.7)$ \\
\hline Middle & $32.7^{\mathrm{b}}( \pm 0.6)$ & $57.6^{\mathrm{ab}}( \pm 5.2)$ & $0.84^{\mathrm{b}}( \pm 0.1)$ & $80.6^{\mathrm{b}}( \pm 2.0)$ \\
\hline Rear & $33.3^{\mathrm{a}}( \pm 0.4)$ & $60.4^{\mathrm{a}}( \pm 6.3)$ & $0.83^{\mathrm{b}}( \pm 0.3)$ & $81.7^{\mathrm{a}}( \pm 1.0)$ \\
\hline Ambient & $29.0^{\mathrm{d}}( \pm 0.8)$ & $56.0^{\mathrm{b}}( \pm 1.5)$ & & \\
\hline \multicolumn{5}{|l|}{ LwiB } \\
\hline Front & $27.0^{\mathrm{c}}( \pm 1.5)$ & $80.7^{\mathrm{b}}( \pm 4.6)$ & $2.59^{\mathrm{a}}( \pm 2.4)$ & $75.6^{b}( \pm 2.3)$ \\
\hline Middle & $28.4^{\mathrm{b}}( \pm 0.9)$ & $81.0^{\mathrm{b}}( \pm 10.5)$ & $1.02^{\mathrm{b}}( \pm 0.3)$ & $78.5^{\mathrm{a}}( \pm 4.0)$ \\
\hline Rear & $28.5^{\mathrm{b}}( \pm 1.1)$ & $85.4^{\mathrm{a}}( \pm 2.5)$ & $1.09^{\mathrm{b}}( \pm 0.3)$ & $79.7^{\mathrm{a}}( \pm 3.2)$ \\
\hline Ambient & $31.0^{\mathrm{a}}( \pm 0.7)$ & $56.0^{\mathrm{c}}( \pm 1.7)$ & & \\
\hline
\end{tabular}

${ }_{\mathrm{a}, \mathrm{b}, \mathrm{c}, \mathrm{d}}$ Different letters on the same column indicate statistical differences mensured by the Tukey test $(\mathrm{p}<0.05)$.

LwoB = Broiler lot without bath. LwiB = Broiler lot with bath.

The microclimate for $\mathrm{LwiB}$ presented temperature that was lower in relation to the ambient temperature by $4.0,2.6$, and $2.5^{\circ} \mathrm{C}$ in the front, middle, and rear regions, respectively (Table 2), indicating that the water bath decreased the truck's thermal charge, as can be seen in the Figure 2 . Table 3 presents the average values for the ambient and truck microclimate temperatures and RHs as well as the transit ventilation air speed and $\mathrm{H}$ of the microclimate for the LwoB and LwiB lots for the $55 \mathrm{~km} / 90 \mathrm{~min}$ journey conditions. The average ambient temperature was $31.0^{\circ} \mathrm{C}$. The LwoB chicken lot had a truck microclimate temperature that was higher than the ambient temperature by $1.8,2.2$, and $3.6^{\circ} \mathrm{C}$ in the front, middle, and rear of the truck, respectively (Table 3). Table 3 shows the microclimate temperature inside the vehicle with LwiB chickens, and the temperatures in the front and middle were lower compared to the ambient temperature, while the temperature in the rear region was the highest of all $(\mathrm{p} \leq 0.05)$. The highest temperature observed in the rear region for both LwoB and LwiB (Table 3) occurred because of lower ventilation in this region and thus lower bird body heat dissipation as the consequence of lower ventilation observed at the rear and middle of the truck.

The temperature and $\mathrm{RH}$ have a direct influence on the loss of broiler latent body heat, and its capacity to support this heat is inversely proportional to the ambient RH index. The higher the RH value, more difficulties the bird faces in ridding itself of internal body heat through the mouth and feathers, and, as consequence, there is an increase in its respiratory frequency (Belay and Teeter, 1993, Oliveira et al. 2006). Interesting results are shown in Table 2 regarding the influence of the water bath treatment. For LwoB at the distance of $15 \mathrm{~km} / 30 \mathrm{~min}$, while the $\mathrm{RH}$ values of both the front and the middle were similar to the ambient RH, the same was not true for the RH in the rear region, which was higher than the ambient $\mathrm{RH}(\mathrm{p} \leq 0.05)$. For the experiment with bath (LwiB) at the same distance, the $\mathrm{RH}$ values within the vehicle were higher in comparison to the ambient $\mathrm{RH}$. While the difference was not observed for both the front and the middle, the rear region presented the highest value for $\mathrm{RH}(\mathrm{p}>0.05)$. For similar experiments for the distance of $55 \mathrm{~km} / 90$ min journey and LwoB, the RHs for all 
microclimate regions were lower than the ambient RH (Table 4), while for LwiB, the RH for all microclimate regions was higher than the ambient
$\mathrm{RH}$. However, the rear region presented an $\mathrm{RH}$ lower than the front and middle regions $(\mathrm{p} \leq 0.05)$.

\section{(A) LwoB}
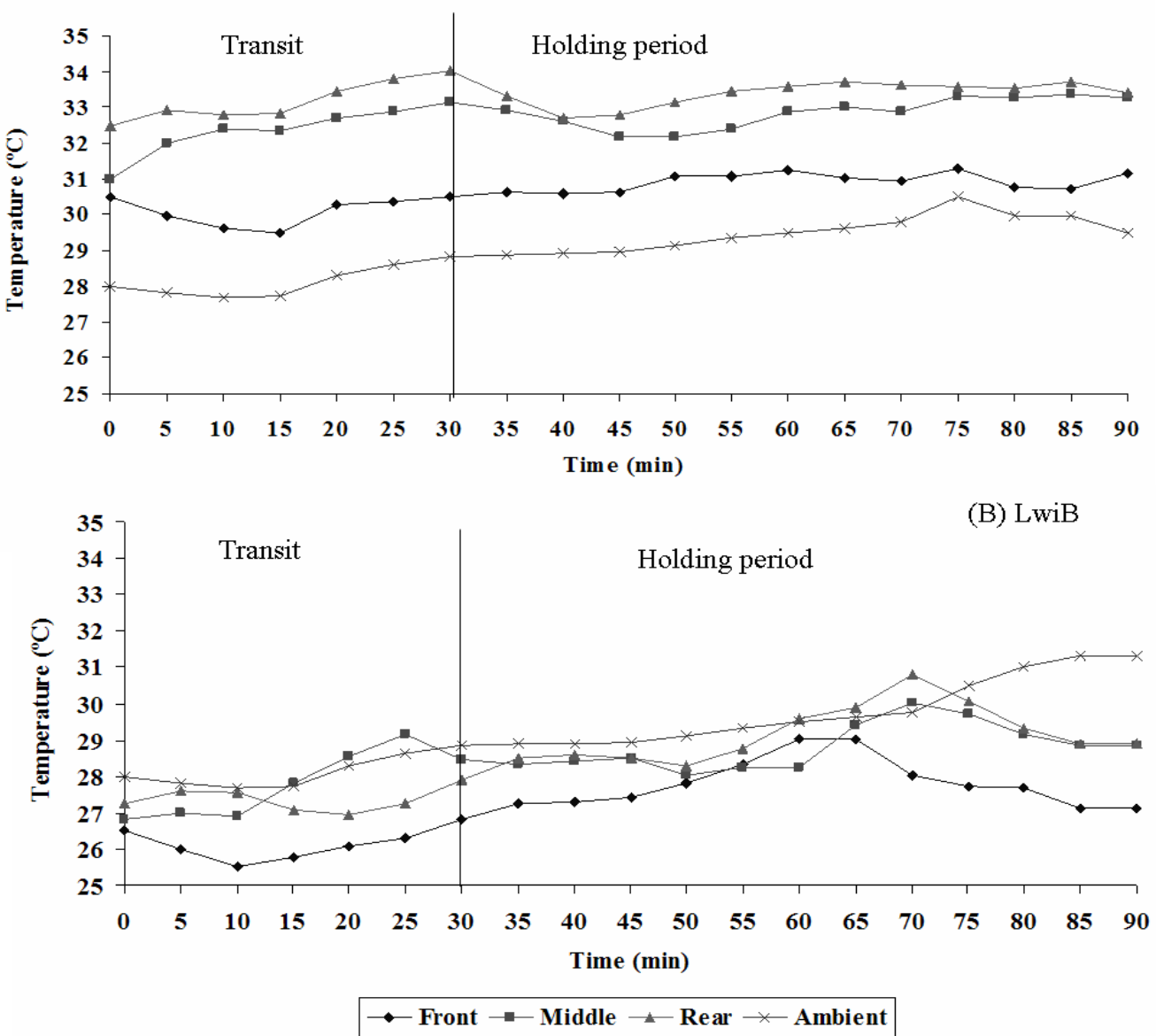

Figure 2 - Time versus temperature in the front, middle and rear regions of the vehicle for birds without bath (LwoB) (A) and with bath (LwiB) (B) on the $15 \mathrm{~km} / 30 \mathrm{~min}$ journey, while at the farm, and for a holding time of $60 \mathrm{~min}$ at the slaughterhouse.

Table 3 - Average values of the ambient temperature $\left(\mathrm{T},{ }^{\circ} \mathrm{C}\right)$ and relative humidity $(\mathrm{RH}, \%)$ and in the vehicle front, middle, and rear regions, ventilation $(\mathrm{VT}, \mathrm{m} / \mathrm{s})$, and enthalpy $(\mathrm{H}, \mathrm{kJ} / \mathrm{kg}$ dry air) of the broiler lot without bath (LwoB) and with bath (LwiB) for the farm $55 \mathrm{~km} / 90 \mathrm{~min}$ from the processing plant.

\begin{tabular}{|c|c|c|c|c|}
\hline Vehicle regions & $\mathrm{T}^{\circ} \mathrm{C}$ & RH\% & VT $\mathrm{m} / \mathrm{s}$ & H kJ/kg dry air \\
\hline \multicolumn{5}{|l|}{ LwoB } \\
\hline Front & $32.8^{\mathrm{c}}( \pm 0.5)$ & $39.7^{\mathrm{b}}( \pm 4.6)$ & $1.35^{\mathrm{a}}( \pm 0.5)$ & $75.4^{\mathrm{b}}( \pm 2.1)$ \\
\hline Middle & $33.2^{\mathrm{b}}( \pm 0.4)$ & $40.2^{\mathrm{b}}( \pm 4.2)$ & $1.05^{\mathrm{b}}( \pm 0.3)$ & $76.1^{\mathrm{b}}( \pm 1.6)$ \\
\hline Rear & $34.6^{\mathrm{a}}(+0.8)$ & $40.7^{b}(+2.6)$ & $0.85^{\mathrm{c}}(+0.3)$ & $79.1^{\mathrm{a}}( \pm 2.0)$ \\
\hline Ambient & $31.0^{\mathrm{d}}( \pm 0.6)$ & $48.9^{\mathrm{a}}( \pm 1.5)$ & & \\
\hline \multicolumn{5}{|l|}{ LwiB } \\
\hline Front & $28.0^{\mathrm{d}}( \pm 1.5)$ & $77.0^{\mathrm{a}}(+7.3)$ & $1.55^{\mathrm{a}}( \pm 0.7)$ & $78.5^{\mathrm{b}}( \pm 2.8)$ \\
\hline Meio & $29.9^{c}( \pm 1.3)$ & $73.5^{\mathrm{a}}( \pm 11.1)$ & $1.07^{\mathrm{b}}( \pm 0.2)$ & $79.4^{\mathrm{ab}}( \pm 2.9)$ \\
\hline Rear & $32.0^{\mathrm{a}}( \pm 1.5)$ & $62.8^{\mathrm{b}}( \pm 13.6)$ & $0.89^{c}( \pm 0.2)$ & $80.4^{\mathrm{a}}( \pm 2.8)$ \\
\hline Ambient & $31.0^{\mathrm{b}}( \pm 0.6)$ & $48.6^{\mathrm{c}}(+1.5)$ & & \\
\hline
\end{tabular}




\section{Ventilation}

The results shown in Tables 2 and 3 demonstrate the importance of ventilation in order to decrease the thermal stress faced by the birds while in transit, irrespective of journey time or holding period. However, the ventilation values are not homogenous and depend on the location inside the vehicle. Ventilation decreases gradually from the front to rear as illustrated in Fig 4 and Fig. 5. Our results indicate that the water bath is an important treatment for keeping the temperature lower than the ambient temperature (Fig. 2 and 3). Similar results were obtained for both the $30 \mathrm{~min}$ and 90 min journeys in relation to the air movement. In the front vehicle region, the average air movement was $4.6 \mathrm{~m} / \mathrm{s}$ and reached a maximum value of 7.0 $\mathrm{m} / \mathrm{s}$ in the first $15 \mathrm{~min}$ of the $30 \mathrm{~min}$ journey (Fig. 4). For the $55 \mathrm{~km} / 90 \mathrm{~min}$ journey, the pattern was different: the ventilation reached a maximum of approximately $3 \mathrm{~m} / \mathrm{s}$ after $35 \mathrm{~min}$ of transit (Fig 5). On this particular day of the experiment, the natural ventilation measured while the birds were at holding was $0.9 \mathrm{~m} / \mathrm{s}$ on average. Obviously, this ventilation is not uniform and depends on several factors, including the vehicle velocity and the natural ventilation; however, it can be established from the results of this experiment that the lowest air movement within the vehicle is in its rear region.

(A) LwoB

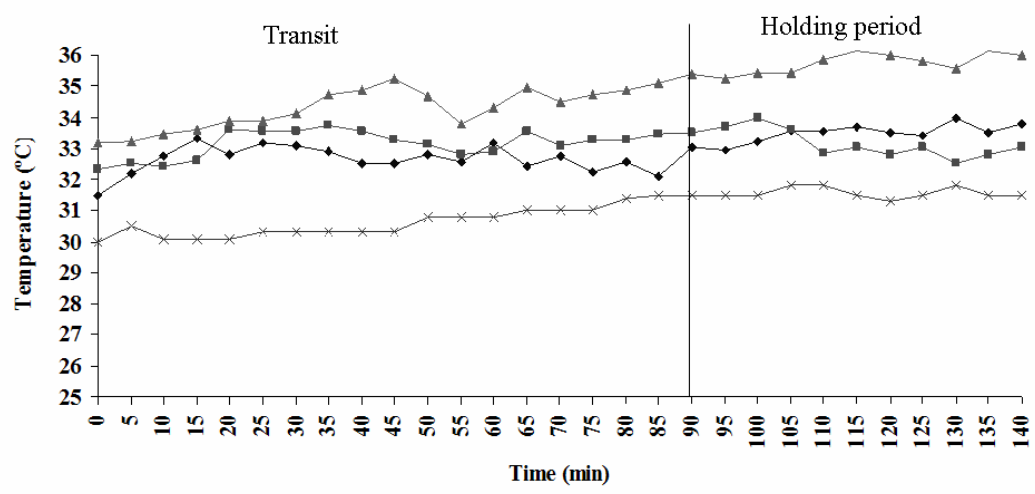

(B) LwiB

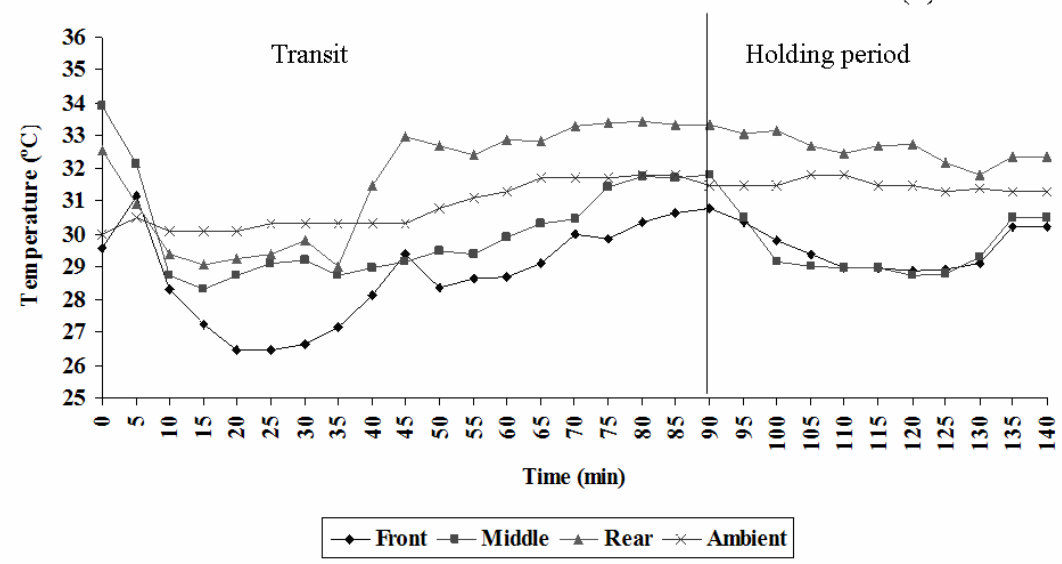

Figure 3 - Time versus temperature in the front, middle, and rear regions of the vehicle for birds without bath (LwoB) (A) and with bath (LwiB) (B) on the $55 \mathrm{~km} / 90 \mathrm{~min}$ journey, while at the farm, and after the holding time of $50 \mathrm{~min}$ at the slaughterhouse.

\section{Enthalpy}

In relation to the CEI for both distances of $15 \mathrm{~km}$ and $55 \mathrm{~km}$, Tables 2 and 3, respectively, show that the rear of the LwoB vehicle had the highest value of $\mathrm{H}$, while for $\mathrm{LwiB}$, the middle and rear regions had higher enthalpy values. Those values are 
explained by the higher temperatures for both LwoB and LwiB (Tables 2 and 3), demonstrating a direct relationship between temperature and $\mathrm{H}$. Enthalpy is defined as the energy from humid air per unit of dry mass; thus, the higher the enthalpy index is, the higher the energy within the environment (Barbosa Filho, 2008). By analyzing the microclimates of $\mathrm{LwoB}$ and $\mathrm{LwiB}$ transported both $15 \mathrm{~km} / 30 \mathrm{~min}$ and $55 \mathrm{~km} / 90 \mathrm{~min}$, we found that $\mathrm{RH}$ values above $80 \%$ are indicative of discomfort in the environment that would lead to a critical zone. Thus, the rear zone of the vehicle, during summer in Brazil, irrespective of the transit conditions for this experiment (Tables 2 and 3) should be characterized as a dangerous region and most likely is similar to the thermal core, as described previously by Mitchell and Kettlewell (1998).

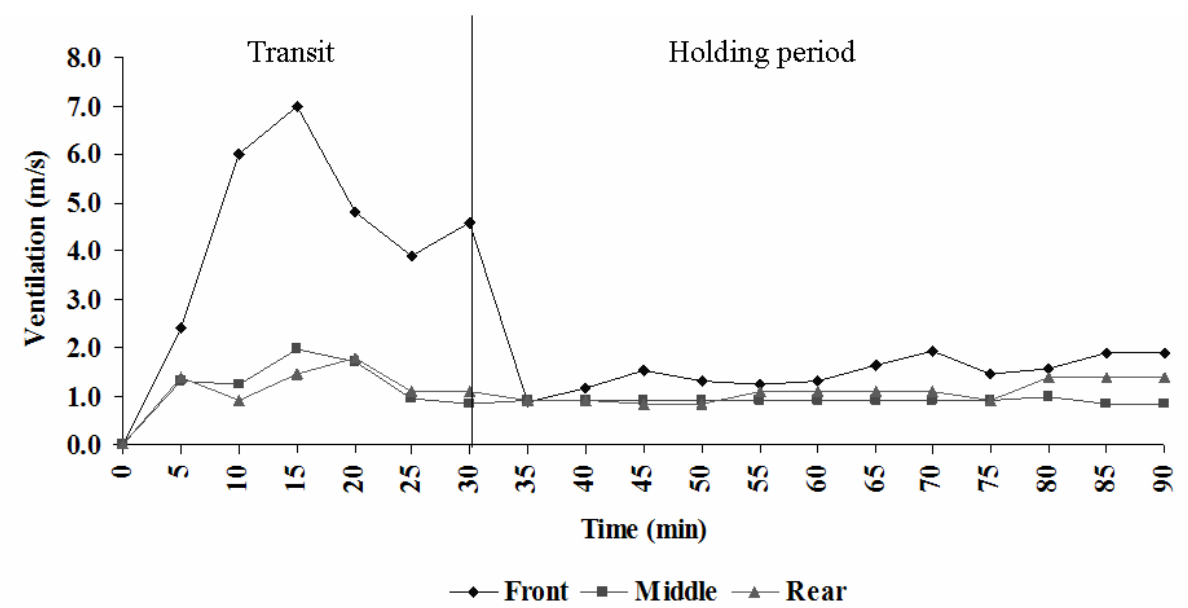

Figure 4 - Time versus ventilation air speed in the front, middle, and rear vehicle regions throughout the $15 \mathrm{~km} / 30 \mathrm{~min}$ journey and $60 \mathrm{~min}$ holding time at the commercial slaughterhouse.

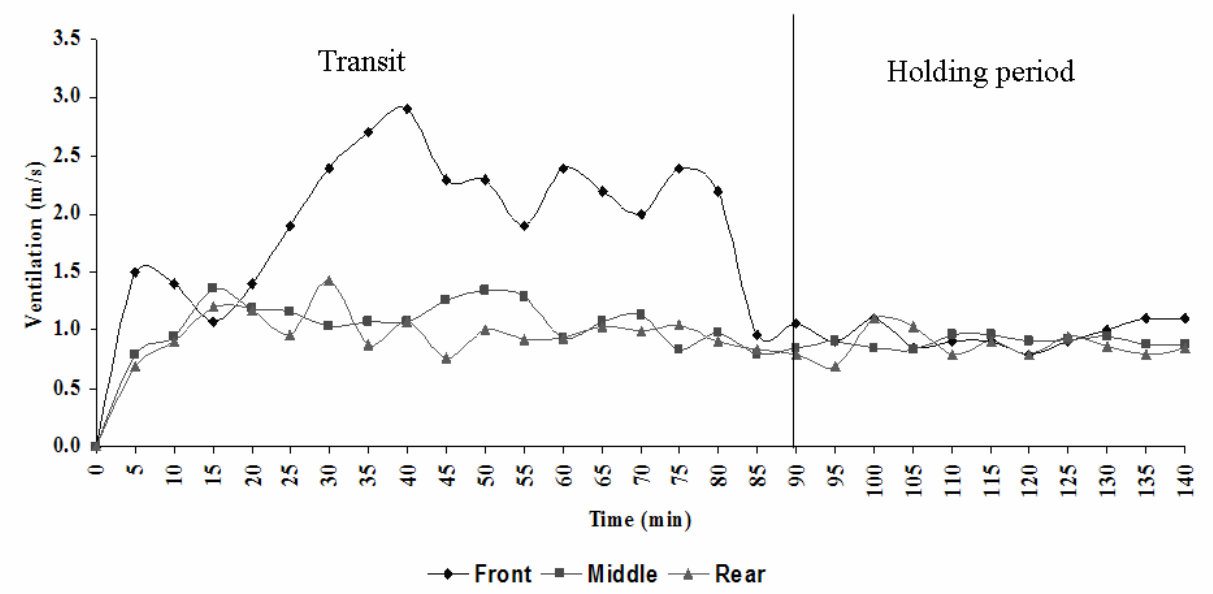

Figure 5 - Time versus ventilation air speed in the front, middle, and rear vehicle regions throughout the $55 \mathrm{~km} / 90 \mathrm{~min}$ journey and the $50 \mathrm{~min}$ holding time at the commercial slaughterhouse. 
Effects of transport conditions on the occurrence of broiler breast PSE meat

As can be observed in Table 4, the highest occurrence of PSE meat for the LwoB lot on the $15 \mathrm{~km} / 30 \mathrm{~min}$ journey was from birds located in the rear of the vehicle, while for LwiB, the highest occurrences were observed in the middle and rear of the vehicle. These results are in accordance with the formation of the thermal core, which is located at the rear of the vehicle. For LwoB, the highest $\mathrm{T}$ value was in the rear, and the higher $\mathrm{T}$ value and lower VT resulted in a CEI value above $80.0 \mathrm{~kJ} / \mathrm{kg}$ dry air (Table 2). For LwiB, the middle and rear zones of the vehicle were the locations where the highest $\mathrm{T}$ values were found. The $\mathrm{RH}$ was also high, but the VT values were lower, and CEI values were near $80.0 \mathrm{~kJ} / \mathrm{kg}$ of dry air. Similar results were obtained for the $55 \mathrm{~km} / 90 \mathrm{~min}$ journey for both LwoB and LwiB (Table 5). The greatest occurrence of PSE meat was obtained from samples located at the rear of the vehicle. These results are the consequence of the location of birds within the vehicle, and those cages located in the rear were in the discomfort danger zones. Moreover, the ventilation in the front has been determined to influence the formation of PSE abnormalities. In each case, birds located in the front produced similar amounts of PSE and normal meat, whereas those located in the middle and rear regions produced higher quantities of PSE meat. These results can be explained by the value of $T$ and RH per si or both associated. Higher $\mathrm{T}$ and $\mathrm{RH}$ values lead directly to a higher formation of PSE meat. Higher ventilation may decrease the temperature. Thus, ventilation was an important factor for controlling the temperature during transit.

Table 4 - Occurrence of PSE and normal meat after the $15 \mathrm{~km} / 30 \mathrm{~min}$ and $55 \mathrm{~km} / 90 \mathrm{~min}$ journeys for birds located in cages in the front, middle, and rear regions of the trucks both without (LwoB) and with (LwiB) a water bath at the farm.

\begin{tabular}{|c|c|c|c|c|}
\hline \multirow{3}{*}{ Vehicle regions } & \multicolumn{2}{|c|}{ LwoB } & \multicolumn{2}{|c|}{ LwiB } \\
\hline & PSE & Normal & PSE & Normal \\
\hline & \multicolumn{2}{|c|}{$\%$} & \multicolumn{2}{|c|}{$\%$} \\
\hline \multicolumn{5}{|c|}{15 km/30 min journey } \\
\hline Front $(\mathrm{n}=60)$ & 35.0 & 65.0 & 32.2 & 67.8 \\
\hline Middle (n=60) & 50.8 & 49.2 & 43.3 & 56.7 \\
\hline Rear $(n=60)$ & 62.7 & 37.3 & 40.0 & 60.0 \\
\hline \multicolumn{5}{|c|}{55 km/90 min journey } \\
\hline Front $(n=60)$ & 53.3 & 46.7 & 51.7 & 48.3 \\
\hline Middle (n=60) & 60.0 & 40.0 & 45.0 & 55.0 \\
\hline Rear $(n=60)$ & 75.0 & 25.0 & 61.7 & 38.3 \\
\hline
\end{tabular}

LwoB = Broiler lot without bath. LwiB = Broiler lot with bath.

\section{Logistic regression analysis}

Logistic regression analysis was used in order to verify the occurrence of PSE meat in relation to the transport, application of the water bath while at the farm after broiler loading, and finally the location of the birds within the vehicle. Table 5 shows the logistic regression analysis and the odds ratio estimates for the occurrence of PSE meat during the summer season. It was verified that the distance/time of $55 \mathrm{~km} / 90 \mathrm{~min}$ had a significant effect ( $\mathrm{p}=0.0002)$ on the occurrence of PSE meat, with $57.8 \%(\mathrm{n}=360)$ frequency of PSE meat and an odds ratio estimate of 1.762 [95\% CI: 1.307 -
2.375], meaning that broilers transported $55 \mathrm{~km} / 90$ min showed a $76.2 \%$ greater possibility of developing PSE meat in comparison those transported $15 \mathrm{~km} / 30 \mathrm{~min}$. The middle and rear vehicle regions showed significant effects on the occurrence of PSE meat, at $51.8 \%(\mathrm{n}=240)$ and $54.6 \%(\mathrm{n}=240)$, respectively. They presented odds ratio estimates of 1.584 [95\% CI: $1.176-2.135$ ] and 1.776 [95\% CI: $1.317-2.395$ ], respectively. These results indicate $58.4 \%$ and $77.6 \%$ greater possibilities of developing PSE for birds in the middle and rear regions, respectively, in comparison to the front region. In relation to the 
water bath, a significant effect on the occurrence of PSE meat was observed for the lot of birds that were not submitted to a water bath, with a $52.2 \%$ $(\mathrm{n}=360)$ possibility and an odds ratio estimate of
1.304 [95\% CI: 1.023 - 1.663], meaning that birds without the water bath had a $30.4 \%$ greater possibility of developing PSE meat.

Table 5 - Logistic regression analysis and hazard estimates for the occurrence of PSE meat, in the summer season and for the distances of $15 \mathrm{~km} / 30 \mathrm{~min}$ and $55 \mathrm{~km} / 90 \mathrm{~min}$.

\begin{tabular}{|c|c|c|c|c|c|}
\hline Factors & PSE (\%) & $p$ value & Odds Ratio & \multicolumn{2}{|c|}{$\begin{array}{c}\text { Confidence interval } \\
(95 \%)\end{array}$} \\
\hline \multicolumn{6}{|c|}{ Distance/time $(\mathrm{km} / \mathrm{min})$} \\
\hline $15(n=360)$ & 44.0 & - & 1.000 & \multicolumn{2}{|c|}{ Reference } \\
\hline $55(n=360)$ & 57.8 & 0.0002 & 1.762 & 1.307 & 2.375 \\
\hline \multicolumn{6}{|l|}{ Vehicle region } \\
\hline Front $(n=240)$ & 40.7 & - & 1.000 & \multicolumn{2}{|c|}{ Reference } \\
\hline Middle $(n=240)$ & 51.8 & 0.0025 & 1.584 & 1.176 & 2.135 \\
\hline $\operatorname{Rear}(n=240)$ & 54.6 & 0.0002 & 1.776 & 1.317 & 2.395 \\
\hline \multicolumn{6}{|l|}{ Water bath } \\
\hline LwiB $(n=360)$ & 45.8 & - & 1.000 & \multicolumn{2}{|c|}{ Reference } \\
\hline LwoB $(n=360)$ & 52.2 & 0.0324 & 1.304 & 1.023 & 1.663 \\
\hline
\end{tabular}

Hosmer-Lemerhow test for lack of fit: $x^{2}=6.0407$.

\section{CONCLUSIONS}

For broiler chicken transportation during the summer season in Brazil, several factors influence the development of PSE meat. A water bath while at the farm reduced the occurrence of PSE meat, and long distances/higher transit times were deleterious to the birds' welfare, producing more PSE meat. The thermal core is formed mainly at the rear of the vehicle, and birds located at this vehicle region produced higher amounts of PSE meat. Ventilation plays a significant role in the formation of PSE meat because birds located at the front of vehicle presented less meat color abnormalities. Thus, a better design is necessary in order to obtain adequate ventilation throughout the vehicle.

\section{ACKNOWLEDGEMENTS}

The financial resources for the conduction of this study were supported by the project BioAgroPar financed by FINEP, SETI/PR, and Fundação Araucária/PR; and by CNPq/Brazil. This work was partially funded by $\mathrm{CNPq}$, Fundação Araucária/CNPq Pronex (Protocol 09.277). Thanks also go to CAPES Foundation for a graduate scholarship to GSS. EII and MS are CNPq Research Fellows.

\section{RESUMO}

O microambiente térmico formado no caminhão de transporte de frangos da granja ao abatedouro pode ser a causa primária que compromete o bem estar das aves e a qualidade final da carne com o desenvolvimento de PSE (Pale, Soft, Exudative) em filés de peito de frango. O objetivo deste trabalho foi avaliar o efeito do microambiente formado durante o transporte por caminhão em uma linha comercial. Para classificação de filés de peito em PSE, o $\mathrm{pH}$ e a cor $\left(\mathrm{L}^{*}, \mathrm{a}^{*} \mathrm{e} \mathrm{b}^{*}\right)$ foram medidos nos filés de peito de frango $24 \mathrm{~h}$ postmortem. Os resultados mostraram que em jornadas longas, as aves transportadas nas regiões do meio e fundo do veículo apresentaram maior ocorrência de PSE devido às drámaticas condições de temperatura e umidade relativa no microambiente destas regiões. A ventilação diminuiu gradualmente da frente à trazeira do caminhão e a aplicação do banho de água sobre os frangos após o carregamento na granja foi benéfica em jornadas longas ao reduzir a ocorrência de carnes PSE. 


\section{REFERENCES}

Barbosa Filho, J. A. D. (2008), Quantiqualitative characterization of bioclimatic and productive conditions on poultry preslaughter operations. 2008. 174 p. Thesis (PhD in Phisics of Agricultural Environment) - Escola Superior de Agricultura "Luiz de Queiroz”, Universidade de São Paulo, Piracicaba.

Barbosa Filho, J. A. D., Vieira, F. M. C., Fonseca, B. H. F., Silva, I. J. O., Garcia, D. B., Hildebrand A. (2008), Poultry Transport Microclimate Analysis through Enthalpy Comfort Index (ECI): A Seasonal Assessment. Núcleo de Pesquisa em Ambiência, Escola Superior de Agricultura "Luiz de Queiroz, Universidade de São Paulo, Piracicaba. Disponível em:

http://www.nupea.esalq.usp.br/noticias/producao/101 3b_20080917.pdf

Belay, T.; Teeter, R. G. (1993), Broiler water balance and thermobalance during thermoneutral and high ambient temperature exposure. Poultry Science, Ithaca, 72, 116-124.

Guarnieri, P. D.; Olivo, R.; Soares, A.; Ida, E. I.; Lara, J. A. F.; Shimokomaki, M. (2004), Bem estar animal e qualidade da carne das aves: uma exigência dos consumidores. São Paulo. Revista Nacional da Carne, 301, 36-44.

Hosmer, D. W.; Lemerhow, S. (1989), Applied logistic regression. New York: John Wiley and Sons.

Langer, R. O. S., Simões, G. S., Soares, A. L., Oba’ A., Rossa, A., Shimokomaki, M., Ida, E. I. (2009),
Broiler Transportation Conditions in a Brazilian Commercial Line and the Occurrence of Breast PSE (Pale, Soft, Exudative) Meat and DFD-like (Dark, Firm, Dry) Meat. Brazilian Archives Biology and Technology (Submitted).

Mitchell, M.A. Kettlewell, P. J. (1998), Physiological stress and welfare of broiler chickens in transit: solutions not problems! Poultry Science, Ithaca, 77, 1803-1814.

Nicol, C. J.; Scott, G. B. (1990), Pre-slaughter handling and transport of broiler-chickens. Applied Animal Behaviour Science, 28, 1-2, 57-73.

Oliveira, R.; Donzele, J.; Abreu, M.; Ferreira, R.; Vaz, R.; Cellas. (2006), P. Efeitos da temperatura e da umidade relativa sobre o desempenho e o rendimento de cortes nobres de frangos de corte de 1 a 49 dias de idade. Viçosa, Revista Brasileira de Zootecnia, , 35 (3), 797-803,

Olivo, R.; Soares, A. L.; Ida, E. I.; Shimokomaki, M. (2001), Dietary Vitamin E inhibits poultry PSE and improves meat function properties. Journal of Food Biochemistry, Trumbull, 25 (4), 271-283.

Soares, A. L.; Lara, J. A. F.; Ida, E. I.; Guarnieri, P. D.; Olivo, R.; Shimokomaki, M. (2002), Variation in the colour of brazilian broiler breast fillet. Proceedings, Roma.. In: International Congress of Meat Science and Technology, 48 540-541,

Terzi, R.G.G.; Guelli, E.; Abreu, H.J.; Baia, L.L. (1997), Índices de Prognósticos em Medicina Intensiva II. Métodos. Revista Brasileira de Terapia Intensiva, 9 (1) 40-49. 